\title{
THE IMPACT OF THE 2009 INDONESIA'S DIVIDEND TAX CUT ON DIVIDEND PAYMENT
}

\author{
( Wayan Agus Eka*) \\ Directorate General of Taxes, Ministry of Finance, Republic of Indonesia \\ wayanaguseka@gmail.com
}

\section{INFORMASI ARTIKEL}

Diterima Pertama

[15042018]

Dinyatakan Diterima

[27112019]

KATA KUNCI:

dividend, tax cut, dividend policy, dividend payment

KLASIFIKASI JEL:

$\mathrm{H} 2 \mathrm{O}$

\section{ABSTRACT}

On January 1, 2009 the effective tax rate for individual-recipient dividend fell significantly from $35 \%$ to $10 \%$. This paper investigated the impact of the dividend tax cut policy on dividend payment in three aspects i.e. extensive margin, intensive margin and dividend per share amount, an adoption from Chetty and Saez (2004) approach. I used publicly available data provided by The Indonesian Stock Exchange and The Indonesian Central Securities Depository. I found that one year after the tax cut policy, the fraction of the firms paying dividend increase and reach its peak in 2011. From intensive margin approach, the percentage of firms that increase their dividend per share amount also increase one year after the policy. Using regression analysis, this paper also found that the tax cut policy increased the dividend per share amount by 35.03 . This study, to my knowledge, provides the first empirical evidence of the effect of dividend tax cut policy and concludes that the policy has positive impact on dividend payment in term of fraction of firms paying dividend, fraction of firms increasing their dividend and the nominal amount of the dividend per share.

Tarif pajak efektif untuk dividen yang diterima orang pribadi turun secara signifikan dari 35\% ke $10 \%$ sejak 1 Januari 2009. Penelitian ini menginvestigasi dampak dari kebijakan pemotongan pajak atas dividen tersebut dalam 3 aspek yang diadopsi dari pendekatan yang digunakan Chetty and Saez (2004) yaitu margin ekstensif, margin intensif dan nilai dividen per lembar saham. Penelitian ini menggunakan data publik yang disediakan oleh Bursa Efek Indonesia dan Kustodian Sentral Efek Indonesia. Penelitian ini menemukan bahwa satu tahun setelah kebijakan pemotongan pajak, persentase jumlah perusahaan yang membayar dividen meningkat dan mencapai puncaknya pada tahun 2011. Dari pendekatan margin intensif, persentase perusahaan yang meningkatkan jumlah dividen per lembar saham juga meningkat satu tahun setelah kebijakan pemotongan dimulai. Berdasarkan analisis regresi, penelitian ini juga menemukan bahwa kebijakan ini meningkatkan jumlah dividen per lembar saham senilai 35,03. Penelitian ini, sejauh sepengetahuan penulis, merupakan penelitian pertama yang menyajikan bukti empiris mengenai dampak kebijakan pemotongan pajak ini dan menyimpulkan bahwa kebijakan ini memberikan pengaruh positif pada pembayaran dividen baik dalam persentase jumlah perusahaan yang membayar, persentase jumlah perusahaan yang meningkatkan jumlah dividen per lembar saham dan nilai nominal dari dividen per lembar saham. 


\section{INTRODUCTION}

On September 23, 2008, President Susilo Bambang Yudhoyono signed the Law Number 36 Year 2008 concerning The Fourth Amendment of the Law Number 7 Year 1983 about Income Tax (hereinafter refer to as $2008 \mathrm{Act}$ ). The 2008 Act came into force on January 1, 2009.

One of the significant changes stipulated in the 2008 Act was tax rate reduction for dividend received by individual. Before the enactment of the 2008 Act, the mechanism for taxing dividend received by individual was consisted of two stages: payment stage and yearend calculation stage. In payment stage, dividend paid by dividend payer was subject to $15 \%$ withholding tax rate. In year-end calculation stage, dividend receiver must aggregate the dividend with other income in the calculation of individual taxable income. This aggregated taxable income was subject to progressive individual tax rate (maximum rate is $35 \%$ ) and allowed withholding tax payment as a tax credit. Therefore, the effective tax rate for dividend received by individual before the enactment of the 2008 Act was 35\%.

Article 17 (2c) of the 2008 Act stipulates that the tax rate for dividend received by individual taxpayer is $10 \%$ and final in substance. Final in substance means that dividend income will not be aggregated with other income in the calculation of the annual taxable income. Thus, the effective tax rate for dividend received by individual shareholder declined to only $10 \%$.

Before the enactment of the 2008 Act, the debate on dividend tax flourished. The Fiscal and Monetary Chief of the Indonesia Industry and Trade Chamber argued that the tax on dividend is a double taxation because dividend has been taxed in company level (Asteria, 2008). In addition, Drajad Wibowo, law maker from National Mandate Party, also argued that tax on dividend will cause entrepreneur move their business to Singapore that implements free tax on dividend (Marga, Cicilia, Prianti \& Rosa, 2008). However, government opposed that arguments by choosing an option to reduce the tax rate on dividend, instead of free tax, as an incentive for individual capital owner. Reducing tax rate on dividend will make investment in stock more attractive than saving the money in bank which will be subject to $20 \%$ tax on interest (Asteria, 2008).

Indonesia uses classical taxation system meaning that corporation and owner are considered as two separate entities and consequently the income received by both entities will be taxed separately. Taxation on dividend is the implementation of this classical system. The 2009 dividend tax cut had three goals (The Directorate General of Taxes [DGT], n.d.):

1. Reducing tax burden for individuals who invest in stock.

2. Encouraging companies to distribute their earning to shareholder.

3. Minimizing administration cost for both taxpayers and DGT.

This paper tries to investigate the impact of the 2008 Act on corporate behavior in dividend payment.
The main purpose of this paper is to evaluate whether the second goal was achieved or not. The paper is organized as follow. Section 2 reviews several relevance literatures. Section 3 describes the data. Section 4 presents the results. Lastly, section 5 offers concluding remarks.

\section{LITERATURE REVIEW}

Indonesia is not the only country implementing dividend tax cut policy. On June 13, 2005, the Ministry of Finance of the People Republic of China reduced the tax base for dividend received by individual to become $50 \%$ resulting a reduction of the effective tax rate on dividend from $20 \%$ to $10 \%$ (Wang \& Guo, 2011). Moreover, on May 28, 2003, US president passed a law that reduced the tax rate on dividend received by individual from the top progressive tax rate $38.1 \%$ to $15 \%$ (Blouin, Raedy \& Shackelford, 2004).

In China's case, Wang and Guo (2011) investigated the impact of China's dividend tax cut on dividend payment. They used natural experiment and difference-in-difference estimator method to study the impact of the policy. Using natural experiment was possible because companies with corporate shareholders were not affected by the policy and could be used as control group (the tax cut policy only affected companies whose share were held by individuals). Wang and Guo (2011) found that the tax cut policy increased dividend payment in China, and companies with large proportion of individual shareholder were more likely to increase dividend payment. Moreover, they also found that companies whose shares were hold by their executives also increased their dividend payment.

US dividend tax cut policy is well-studied in the literature. Dividend in The US has been declining for long time, and the enactment of the Jobs and Growth Tax Relief Reconciliation Act of 2003 (2003 Act) tried to invert this trend (Blouin, Raedy \& Shackelford, 2004). Chetty and Saez (2004) carefully studied the impact of the policy by using quarterly data from 1980 to 2004 provided by Center for Research in Security Prices (CRSP). They found, first, the portion of publicly listed companies paying dividend increased in 2003 after declining for more than 20 years. Second, companies that regularly paid dividend before the tax cut policy increased their dividend payment after the policy. Third, the positive impact of the tax cut was also found not only in the regular dividend but also in special dividend.

The impact of the US dividend tax cut policy was also investigated by Blouin, Raedy and Shackelford (2004). They used sample of company for period six month before and after the enactment of the law (May 23,2003 ) resulting about 1,463 companies. They found a $10 \%$ increase in total regular dividend 6 months following the enactment of the law (Blouin, Raedy \& Shackelford, 2004). Similar with Wang and Guo (2011), Blouin, Raedy and Shackelford (2004) also found evidence of increase dividend for insider ownership. Lastly, they also found an increase in individual share in the company's capital structure after the enactment of the law. 
This paper, to my knowledge, is the first paper that investigates the impact of the 2009 Indonesia's dividend tax cut policy. Considering that the Indonesia's policy, to some extent, is similar to the US tax cut policy and due to data constraint, I use a similar analysis technique as used by Chetty and Saez (2004) with several modifications.

\section{DATA}

This paper uses sample from publicly traded firms listed in the Indonesian Stock Exchange. The list of the company was derived from data provided by Indonesian Stock Exchange at http://www.idx.co.id/idid/beranda/perusahaantercatat/profilperusahaanterc atat.aspx. As of July 2014, there was 502 listed companies. Since the aim of this paper is investigating changes in firm dividend policy over time and considering that the tax cut was enacted at early 2009, I require the companies to be listed from January 1 , 2003 and remove the firms that were newly listed or delisted afterwards, resulting 307 companies.

Those 307 companies then merged with cash dividend data (in dividend per share) from 2003 to 2013 provided by The Indonesian Central Securities Depository that could be publicly downloaded from http://www.ksei.co.id/support/data_user_guide. This merged data (hereinafter refer to as the core data) is the main data used in the analysis of this paper. The descriptive statistic for the cash dividend data is as follows.

Table 1: Descriptive Statistics

\begin{tabular}{clllll}
\hline $\begin{array}{c}\text { Varia } \\
\text { ble }\end{array}$ & Obs & Mean & $\begin{array}{c}\text { Std. } \\
\text { Dev. }\end{array}$ & $\begin{array}{l}\text { M } \\
\text { in }\end{array}$ & Max \\
\hline Div & 3,377 & 105.867 & 864.742 & 0 & 24,074 \\
\hline
\end{tabular}

Source: Stata output

\section{RESULTS}

Because of the similarity of tax cut policy between Indonesia and the US, the analyses of this paper follow Chetty and Saez (2004) with slight modifications. First, I will discuss about the extensive margin i.e. fraction of dividend payer and initiations/terminations of annual dividend. Second, I will discuss about the intensive margin i.e. increase or decrease in dividend payment. Third, I will discuss about the impact of the tax cut policy on dividend per share.

\subsection{Extensive Margin}

Extensive margin analyzes the impact of the dividend tax cut policy on two indicators: fraction of dividend payers and fraction of firms initiating or terminating dividend payment (Chetty and Saez, 2004).
Fraction of dividend payers

Figure 1: Fraction of firms paying dividend

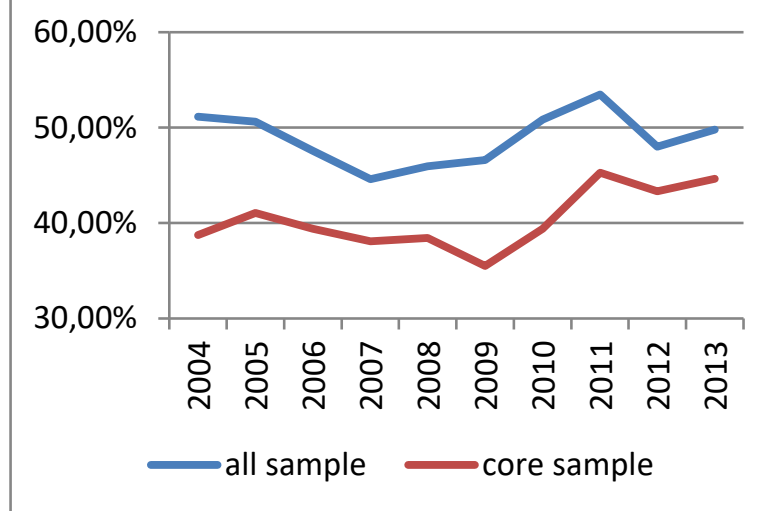

Source: own calculation based on data from Indonesian Central Securities Depository

Figure 1 plots the fraction of dividend payers between 2004 and 2013 for both all sample (the initial sample) and the core sample (the 307 companies). For all sample (the blue line) we can see that the fraction of dividend payers decreased from 51\% in 2004 to $44 \%$ in 2007 and started to increase afterward until reach its peak in 2011. From this all sample line, there was a clear increase in 2010-2011 (1 year after the 2008 act was enacted) suggesting that the effect of the tax cut policy may need time (a lag) to affect firms' dividend decision.

Using all sample, to some extent, could result bias since the number of firms each year was not constant because some companies were newly listed as well as delisted. To address this issue, I use the core sample that has a constant-size sample, the same technique that was used by Chetty and Saez (2004). The red line in Figure 1 shows the fraction of dividend payers for core sample. In 2004, around $38 \%$ of the listed company paid dividend and this number decreased to around $35 \%$ in 2009 . One year after the enactment of the 2008 act, however, the fraction of dividend payer start increasing to $40 \%$ in 2010 and reach $45 \%$ a year later. Hence, the tax cut policy might started to give effect one year after the enactment of the 2008 act.

\section{Initiations and terminations}

This subsection investigates why the fraction of dividend payers increased significantly in period 20102011 by analyzing the impact of the tax cut policy on initiations and terminations of annual cash dividend. Principally, the initiation and termination method used in this paper is adopted from Chetty and Saez (2004). However, this paper defines initiating dividend in year $t$ if the firm pays dividend in year $t$ and did not pay dividend in year $\mathrm{t}-1$ and $\mathrm{t}-2$; and terminating dividend payment in year $t$ if the firm paid dividend in year $t-1$ but does not pay dividend in year $t$ and $t+1$. 
Figure 2: Dividend Initiation and Termination

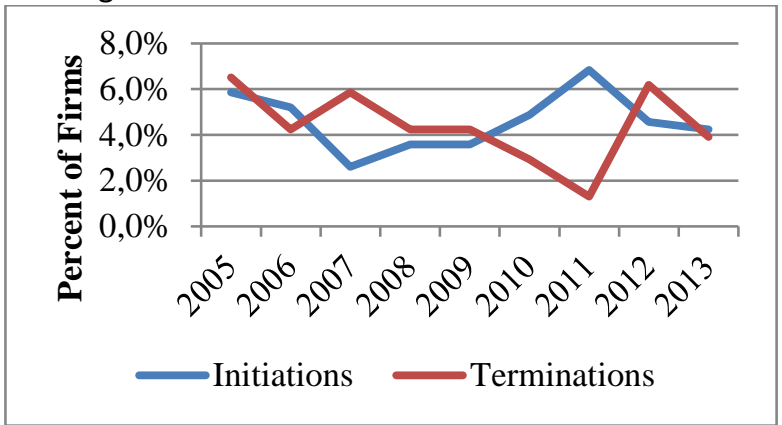

Source: Own calculation based on data from Indonesian Central Securities Depository

Figure 2 shows the fraction of initiating and terminating dividend for core sample. Figure 2 implies that the fraction of terminating company fluctuated before the 2008 Act and decreased afterward until reach its lowest position in 2011 where only around 1\% of the company who terminate dividend payment. For initiating company, we also can see a decrease trend until 2007 and increased until 2011 where around 7\% of the company who initiate dividend payment. More importantly, we can see a clear opposite direction between initiation and termination line between period 2010 and 2011. This fact provides explanation why the fraction of dividend payer in Figure 1 increased in 2010-2011 and support previous argument that the tax cut policy need one year lag to give an impact.

\subsection{Intensive Margin}

Intensive margin analysis tries to investigate whether the tax cut policy affect the amount of dividend payment. To exclude the effect of inflation, the amount of dividend per share used in this analysis is transformed into real term 2009. In this paper, firm defines as increasing intensive margin if the dividend per share paid in year $t$ was larger than year $t-1$, vice versa.

Figure 3. Intensive margin: dividend increase and dividend decrease

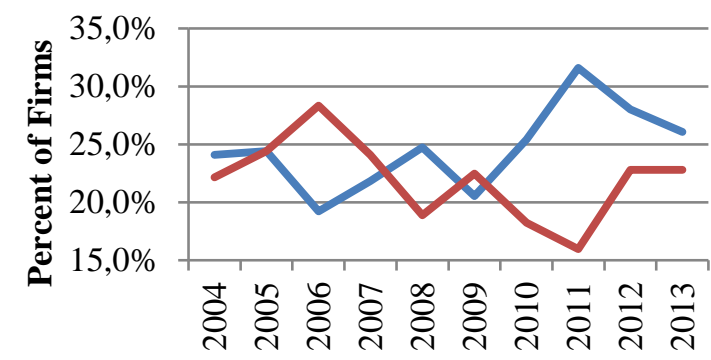

dividend increase dividend decrease

Source: Own calculation based on data from Indonesian Central Securities Depository

Figure 3 shows fraction of firms with increase and decrease dividend from 2004 to 2013. Before 2009, the fraction of firms that increase or decrease their dividend payment fluctuated. However, for period 2010-2011, one until two year after the enactment of the 2008 Act, fraction of firms that increased their dividend jump significantly and conversely fraction of firms that reduced their dividend fall significantly. In 2011, its largest gap, $31 \%$ of the companies increase their dividend payment where only $16 \%$ of the companies decrease their dividend payment. Thus, the 2008 Act also affected firms to increase their dividend payment but similar like previous finding the effect took place one year after the enactment.

\subsection{Dividend per Share Amount}

Chetty and Saez (2004) also investigated the impact of the US dividend tax cut policy on the total amount of dividend. Due to the lack of data, however, this paper could not do the same analysis, and alternatively this paper will study the impact of the policy on dividend per share. To address inflation issue, I transform the nominal amount of dividend per share into 2009 real Rupiah value.

Figure 4. Average dividend per share (2009 real Rupiah value) from core sample

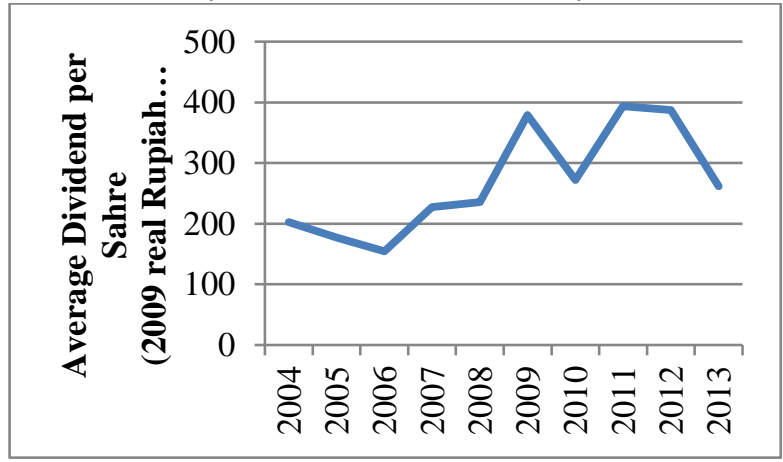

Source: Own calculation based on data from Indonesian Central Securities Depository

Figure 4 shows the average of dividend per share from the core sample from 2004 to 2013. Figure 4 shows that the average dividend per share after the enactment of the 2008 Act is relatively higher than before. For a robust conclusion, I estimate the impact of the tax cut policy using similar dividend payout model used by Chetty and Saez (2004). The estimation is as follows:

$$
\begin{gathered}
d i v_{i t}=\delta \operatorname{taxcut}_{t}+\pi l 1_{-} d i v_{i t}+\theta l 2_{-} d i v_{i t}+\lambda Z_{i} \\
+\gamma T_{t}+\varepsilon_{i t}
\end{gathered}
$$

where $i$ is for listed companies; $t$ is for year; div is dividend per share; taxcut is a dummy variable that equals to 1 from 2009 onward and equals to 0 otherwise; I1_div and 12_div are lag of annual dividend meaning dividend payment at $\mathrm{t}-1$ and $\mathrm{t}-2$ respectively; $Z$ and $T$ are for company's fixed effect and year fixed effect respectively. 
Table 2: The Impact of Dividend Tax Cut Policy on Dividend per Share

\begin{tabular}{llll}
\hline & $\begin{array}{l}(1) \\
\text { div }\end{array}$ & $\begin{array}{l}(2) \\
\text { div }\end{array}$ & $\begin{array}{l}(3) \\
\text { div }\end{array}$ \\
\hline \multirow{2}{*}{ taxcut } & & & \\
& 12.34 & $35.03 * *$ & -22.11 \\
$11 \_d i v$ & $(14.20)$ & $(16.95)$ & $(31.49)$ \\
& $0.588 * * *$ & 0.331 & 0.332 \\
12_div & $(0.221)$ & $(0.255)$ & $(0.254)$ \\
& 0.339 & 0.181 & 0.182 \\
Constant & $(0.273)$ & $(0.248)$ & $(0.247)$ \\
& 8.259 & $39.37 * *$ & 50.77 \\
& $(14.96)$ & $(19.83)$ & $(32.05)$
\end{tabular}

F-test; p-value in bracket:

\begin{tabular}{llll} 
year dummy=0 & - & - & 1.12 \\
& & & $(0.347)$ \\
Company's FE & No & Yes & Yes \\
Year FE & No & No & Yes \\
Observations & 2,763 & 2,763 & 2,763 \\
Adj. R-squared & 0.62 & 0.66 & 0.66 \\
\hline
\end{tabular}

Note:

Robust standard errors in parentheses; ${ }^{* * *} \mathrm{p}<0.01, * *$ $p<0.05, * p<0.1$

Table 2 provides three regression results for the estimation. Before controlling company's fixed effect and year fixed effect, regression 1 shows that the tax cut policy did not affect the dividend per share. Then, regression 2 includes the company's fixed effect that controls firm's fixed characteristics such as industry type. When the company's fixed effect was included, the result shows that the tax cut policy significantly increased the dividend per share by 35.03. In the last regression, when year fixed effect was added, the coefficient of the tax cut policy becomes not significant. However, the post-test estimation for the year dummy in the third regression suggests that we cannot reject the null hypothesis meaning that the coefficient of the year dummy is not significantly different from zero. In other words, the F-test for the year dummy suggests that the year fixed effect does not belong to the model. This fact suggests that the second regression is more appropriate for interpretation. Therefore, we can conclude that the tax cut policy significantly affected the dividend per share by 35.03 .

\section{CONCLUSION AND FUTURE STUDIES}

Based on the analyses, this paper concludes the impact of the 2008 Act in several dimensions. First, the dividend tax cut policy increased fraction of firms paying dividend especially one year after the 2008 Act was enacted. This finding is also supported by the fact that the fraction of firms initiating and terminating paying dividend moved in completely separate direction during the same period. Second, the 2008 Act also increased fraction of firms that increasing their dividend payment and reduced fraction of firms that reducing their dividend payment. Lastly, the regression analysis shows that the 2008 Act significantly increased the dividend per share amount by 35.03 .

This paper, to my knowledge, provides the first empirical evidence of the 2008 Act impact. However, future studies are still needed to get a more robust conclusion by utilizing micro level company data to control several possible omitted variables in the regression equation. In addition, future studies could also investigate the impact of the policy on stock repurchase and capital structure.

\section{REFERENCES}

Asteria. (2008, July 4). Pajak dividen ganggu industri [Tax on dividend harms industry]. Inilahcom. Retrieved July 31, 2014, from http://m.inilah.com/read/detail/36820/pajakdividen-ganggu-industri

Blouin, J.L., Raedy, J.S., and Shackelford, D.A. (2004). Did dividends increase immediately after the 2003 reduction in tax rate? NBER Working Paper Number 10301.

Chetty, R., and Saez, E. (2004). Do dividend payments respond to taxes? Preliminary evidence from the 2003 dividend tax cut. NBER Working Paper Number 10572.

Law of The Republic of Indonesia Number 36 Year 2008 Concerning The Fourth Amendment of Law Number 7 Year 1983 about Income Tax (in Indonesian). Retrieved November 1, 2013 from http://www.pajak.go.id/dmdocuments/UU-362008.pdf

Marga, Cicilia, S., Prianti, M., and Rosa, E. (2008, June 27). Masih terganjal soal PTKP, pajak dividend, dan warisan [The new tax law draft still debate about individual allowance, dividend tax and inheritance tax]. Harian Kontan. Retrieved July 31,2014 , from

http://pajak.com/index.php?option=com_content $\&$ task=view \&id=1122\&Itemid $=48$

The Directorate General of Taxes. (n.d.).Main amendments in the Income Tax Law (in Indonesian). Unpublished document.

Wang, C.F., and Guo, Y. (2011). Do dividend tax cuts lead firms to increase dividends: Evidence from China. China Journal of Accounting Research, 4, 197-209. 